\title{
ORGANIZATION CITIZENSHIP BEHAVIOR GURU DAPAT DITINGKATKAN DENGAN KOMITMEN ORGANISASI DAN KECERDASAN SPIRITUAL
}

\author{
Andri Kusmayadi $^{a)}$, Sumardi $^{b)}$, Rais Hidayat ${ }^{\left.b^{*}\right)}$, Farida Wulandari ${ }^{b)}$ \\ a) SMK Madinatulquran, Bogor, Indonesia \\ ${ }^{b)}$ Universitas Pakuan, Bogor, Indonesia \\ ${ }^{*}$ e-mail korespondensi: rais.hidayat@unpak.ac.id
}

riwayat artikel : diterima: 16 November 2019; direvisi: 19 Desember 2019; disetujui: 06 Januari 2020

\begin{abstract}
Abstrak. Penelitian ini bertujuan untuk menemukan upaya peningkatan Organizational Citizenship Behavior (OCB) melalui penelitian terhadap hubungan antara komitmen organisasi dan kecerdasan spiritual dengan $O C B$. Metode penelitian ini adalah deskrikriptif korelasional dengan menggunakan pendekatan kuantitatif. Populasi dalam penelitian ini Guru Tidak Tetap Yayasan (GTTY) pada 14 SMP Swasta yang berada di Kecamatan Jonggol Kabupaten Bogor dengan jumlah 136 orang guru. Teknik pengambilan sampel menggunakan proportional random sampling dengan margin eror 5\% dengan jumlah sampel sebanyak 102 orang guru. Temuan penelitian ini: 1) Terdapat hubungan positif antara komitmen organisasi dengan $O C B$. Kekuatan hubungan antara komitmen organisasi $\left(\mathrm{X}_{1}\right)$ dengan $O C B(\mathrm{Y})$ ditunjukan dengan koefisien korelasi $\mathrm{r}_{\mathrm{y} 1}=0.848$ dan Komitmen Organisasi memberikan kontribusi $71,9 \%$ terhadap $O C B$. 2) Terdapat hubungan positif antara Kecerdasan Spiritual dengan $O C B$. Kekuatan hubungan antara Kecerdasan Spiritual $\left(\mathrm{X}_{2}\right)$ dengan $O C B(\mathrm{Y})$ ditunjukan dengan Koefisien Korelasi $\mathrm{r}_{\mathrm{y} 2}=0.786$ dan Kecerdasan Spiritual memberikan kontribusi $61,8 \%$ terhadap $O C B$. 3) Terdapat hubungan positif antara Komitmen Organisasi $\left(\mathrm{X}_{1}\right)$ dan Kecerdasan Spiritual $\left(\mathrm{X}_{2}\right)$ secara bersama-sama dengan $O C B(\mathrm{Y})$ yang ditunjukan dengan Koefisien Korelasi $\mathrm{r}_{\mathrm{y} 12}=0,848$ dan Komitmen Organisasi dan Kecerdasan Spiritual secara bersama-sama mempunyai kontribusi sebesar 71,9\% terhadap $O C B$. Berdasarkan temuan tersebut OCB guru dapat ditingkatkan melalui peningkatan komitmen organisasi dan kecerdasan spiritual
\end{abstract}

Kata Kunci: Komitmen Organisasi, Kecerdasan Spiritual, OCB.

\section{ORGANIZATION CITIZENSHIP BEHAVIOR TEACHERS CAN BE ENHANCED WITH SPIRITUAL ORGANIZATION AND INTELLIGENCE COMMITMENTS}

\begin{abstract}
The research aimed to find the relationship between organizational commitment and spiritual intelligence with Organizational Citizenship Behaviour (OCB). The method used in this research was a correlational descriptive method using a quantitative approach. The population in this research took 136 the non-permanent teachers who work seperatelly at 14 private junior high schools located in the district of Jonggol Bogor Regency. The sampling technique was using proportional random sampling in Slovin formula with $5 \%$ margin error with a sample amount of 102 teachers. This study resulted in a conclusion; 1) there was a positive relationship between the organizational commitment with OCB. The strength of the relationship between organizational commitment $\left(\mathrm{X}_{1}\right)$ and $\mathrm{OCB}(\mathrm{Y})$ was demonstrated by the correlation coefficient ry $\mathrm{y}_{1}=0848$ and the organizational commitment contributed $71.9 \%$ to the OCB, 2) There was a positive relationship between spiritual intelligence with OCB. The strength of the relationship between Spiritual Intelligence $\left(\mathrm{X}_{2}\right)$ and $\mathrm{OCB}(\mathrm{Y})$ was demonstrated by the correlation coefficient ry $\mathrm{r}_{2}=0,786$ and Spiritual Intelligence contributed $61.8 \%$ to the OCB, 3) There was a positive relationship between the organizational commitment $\left(\mathrm{X}_{1}\right)$ and spiritual intelligence $\left(\mathrm{X}_{2}\right)$ jointly with the OCB $(\mathrm{Y})$ shown with the correlation coefficient $\mathrm{ry}_{12}=0.848$ and the organizational and intelligence commitments Spiritual collectively contributed $71.9 \%$ to the OCB. Based on the findings, the OCB of teachers can be improved through organizational commitment and spiritual intelligence.
\end{abstract}

Keywords: Organizational commitment, Spiritual Intelligence, OCB

\section{PENDAHULUAN}

Lembaga pendidikan perlu melakukan pendekatan terhadap sistem organisasi/lembaga yang mempunyai sistem manajerial SDM yang bagus. Pada era sekarang banyak kajian baru dan menarik dimana manusia dijadikan sebagai subjek dan objek dalam penelitian. Kajian tersebut bertujuan untuk mencari hal yang baru yang dapat dijadikan sebagai peningkatan kemampuan SDM.

Lingkungan kerja yang kondusif merupakan lingkungan yang baik untuk keberlangsungan dan kemajuan suatu lembaga, maka iklim kekeluargaan dan kebersamaan perlu ditingkatkan seperti perilaku saling menolong, peduli akan sesama rekan kerja, saling mengingatkan kesadaran akan tanggungjawab dalam pekerjaan, ramah dan hotmat terhadap sesama rekan kerja, atasan dan orang yang tidak dikenal, dan lain sebagainya. Hal seperti ini perlu menjadi budaya khususnya dalam lingkungan kerja agar lebih mudah untuk mencapai tujuan organisasi atau lembaga. 
Sebagai investasi jangka panjang, pendidikan harus ditata dan disiapkan dari semua yang berkaitan dengan pendidikan baik dari sarana dan prasarana maupun dari seluruh SDM yang terlibat didalamya. Hal ini dilakukan agar pelaku pendidikan bisa mencapai kompetensi yang diharapkan, yakni perpaduan pengetahuan (knowledge), sikap (attitude), dan keterampilan (skill). Ketiga kompetensi ini dapat diimplementasikan dalam kehidupan sehari-hari dengan tujuan untuk memfilter diri dari arus globalisasi yang semakin kuat.

\section{Organizational Citizenship Behavior (OCB)}

Menurut Organ (2006), Podsakoff, dan Mackenzi (1994) bahwa Organizational Citizenship Behavior (OCB) atau perilaku kewargaan organisasional merupakan perilaku individu yang bersifat sukarela, tidak secara langsung mendapat penghargaan dari sistem reward formal, dan secara keseluruhan mendorong efisiensi serta kekefektifan fungsi organisasi. Dimensi OCB meliputi: a. Altruism: menolong rekan kerja yang relevan dengan organisasi, b. Conscientiousness: melampaui persyaratan minimum, c. Sportmanship: toleransi pada keadaan yang tidak ideal (menghindari keluhan), d. Courtesy: mencegah permasalahan yang berhubungan dengan pekerjaan, dan e. Civic Virtue: Bertanggungjawab dan berpartisipasi dalam kegiatan organisasi.

Colquit, Lepine, dan Wesson (2009: 43) menjelaskan bahwa perilaku kewargaan organisasional (OCB) adalah kegiatan sukarela karyawan yang dapat atau tidak diberi imbalan namun berkontribusi pada organisasi dngan meningkatkan kualitas keseluruhan dimana pekerjaan berlangsung. OCB dibagi menjadi dua, yaitu: a. OCB Interpersonal, dimensi OCB ini mencakup: 1) Helping (Menolong rekan kerja), 2) Courtesy (menjaga rahasia rekan kerja), dan b. OCB Organisasi, dimensi ini meliputi: 1) Voice (Memberi pendapat untuk kemajuan organisasi), 2) Civic Virtue (Berpartisipasi, seperti menghadiri rapat dan menjaga informasi organisasi) dan 3) Booterism (Bersikap positif terhadap organisasi ketika di depan umum/jauh dari organisasi). Kreitner dan Kinicki (2014:173) OCB merupakan perilaku-perilaku pegawai diluar tugas. Yang meliputi: a. Memberi pendapat dan saran yang konstruktif, b. Berminat terhadap pekerjaan, c. Pelatiahan pegawai baru, d. Menghormati dan semangat dalm pemeliharaan asset, e. waktu dan kehadiran di atas standard yang ditentukan. Patras (2017:2) mendefinisikan OCB merupakan perilaku seseorang yang melakukan tugas dan fungsinya melebihi apa yang sudah dideskripsikan dalam pekerjaanya (extra role ) atas kesadaran sendiri untuk membantu organisasi mencapai tujuan.

Berdasarkan beberapa kajian teori di atas dapat ditarik sebuah sintesis bahwa $O C B$ adalah suatu perilaku kerja yang dimiliki oleh seorang guru dalam suatu organisasi atau lembaga yang dilakukan secara sukarela dan tidak mengharapkan imbalan di luar tugas pokok yang telah ditetepkan dan disepakati yang memberikan kontribusi kepada organisasi atau lembaga tempat guru bekerja.

\section{Komitmen Organisasi}

Guru dituntut untuk memiliki komitmen organisasi (Hidayat, 2017). Menurut Colquit, Lapine and Waston (2009: 67) bahwa komitmen organisasi merupakan suatu keinginan yang kuat dari seorang karyawan untuk menjadi bagian dari organisasi. Selanjutnya Colquit, Lapine and Waston (2009: 67) membagi komitmen menjadi tiga dimensi yaitu komitmen afektif (affective commitment), komitmen kontinuan (continuance commitment) dan komitmen nortmatif (normatifve commitment). Adapun factor-faktornya sebagai berikut: a. Komitmen Afektif dengan faktor-faktor: kondisi pekerjaan, pemenuhan harapan. b. Komitmen Kontinuan dengan faktor-faktor: kesedian pekerjaan, nilai investasi yang telah dikeluarkan. c. Komitmen Normatif denga faktor-faktor: nilai pribadi, merasa kewajiban.

Gibson (2009: 129) mendefinisikan komitmen organisasi sebagai sikap atau keinginan yang timbul dari dalam individu, untuk menetapkan rasa setia serta melibatkan kesungguhan pada suatu organisasi untuk mencapai tujuan organisasi tersebut, adapun faktor-faktor yang mendukung komitmen tersebut adalah keinginan untuk mencapai tujuan organisasi, keinginan melibatkan dalam organisasi, dan keinginan setia pada organisasi.

Mowday, Steers dan Porter dalam Sutrisno (2010: 295) menjelaskan bahwa komitmen organisasi merupakan upaya pencapaian tujuan organisasi dengan kemauan mengarahkan segala daya untuk kepentingan organisasi dan ketertarikan untuk tetap menjadi bagian dalam organisasi, dengan faktor pendukung dengan adanya keuntungan bila bertahan dalam organisasi dan adanya kelompok yang menjadi alat mencapai keuntungan.

Luthans (2011: 147) mendefinisikan komitmen organisasi merupakan: a. tetap bertahan dalam organisasi, b. kemauan untuk menyerahkan tingkat tinggi usaha atas nama organisasi, c. keyakinan pasti dalam penerimaan nilai-nilai dan tujuan organisasi.

Berdasarkan uraian teori-teori di atas bahwa komitmen organisasi adalah suatu keinginan yang kuat untuk mengidentifikasi dan melibatkan diri dalam suatu organisasi untuk menjadi satu kesatuan dalam organisasi tersebut yang dibuktikan dengan sikap loyalitas untuk tetap bertahan menjadi anggota organisasi dan berusaha sekuat tenaga dalam mencapai tujuan organisasi.

\section{Kecerdasan Spiritual}

Zohar (2007:107) menyatakan bahwa kecerdasan spiritual berkaitan dnegan kecerdasan untuk mengatasi suatu masalah dan menerima suatu nilai. Kecerdasan ini juga terkait dengan kecerdasan untuk berperilaku dan menjalani hidup dalam konteks 
makna yang lebih luas dan kaya, atau kecerdasan untuk menilai suatu tindakan atau kehidupan seseorang lebih bermakna dibanding dengan orang lain.

Buzan (2003 : 241) mendefinisikan bahwa kecerdasan spiritual adalah yang berkaitan dengan menjadi bagian dari rancangan segala sesuatu yang lebih besar, meliputi "melihat suatu gambaran secara menyeluruh" dengan ciri-ciri: (a) Berinteraksi secara efektif; (b) Octal Awareness; (c) Social facility; (d) Pencarian jalan keluar dari konflik antar sesama; (e) Memiliki tingkat kesadaran yang tinggi.

Esmaili et. all (2014: 51) menyatakan bahwa kecerdasan spiritual adalah kemungkinan untuk mengidentifikasi dan menyeimbangkan nilai-nilai seseorang pada pemahaman yang objektif, memperbaiki nilai-nilai tanpa kompromi, jujur, dapat mengenali arti yang sebenarnya dari suatu peristiwa dan keadaan, dan menciptakan aktivitas dan kerja yang berarti, indikator dari kecerdasan spiritual adalah: a. Percaya Tuhan dan spiritualitas (Belief in God and Spirituality), b. Kesadaran diri (Self awareness), c. kebermaknaan dan tujuan dalam hidup (meaningfulness and aim in work), d. Menyelarasskan tujuan individu dan organisasi (Aligning individual and organizational goal), e. Berpikir kritis eksistensial ( Existential critical thinking), f. Membuat makna pribadi ( Creating Personal meaning), g. Memiliki semangat meelayani (Having spirit of serve), h. Keyakinan praktik spiritual dan agama (Spiritual and religious belief and practices), i. Memiiki tujuan transedental dalam kehidupan dan pekerjaan (Having trancedental goals in life and work).

Berdasarkan kajian paparan di atas dapat disintesiskan bahwa kecerdasan spiritual merupakan respon individu untuk bersikap fleksibel, kesadaran diri akan tujuan hidup, mampu menghadapi dan memanfaatkan penderitaan, menghadapi dan melampaui perasaan sakit, keengganan untuk menyebabkan kerugian, kualitas hidup, mampu berpandangan holistik dan kecenderungan untuk bertanya.

\section{METODE PENELITIAN}

Metode yang digunakan dalam penelitian ini adalah metode deskriptif korelasional dengan menggunakan pendekatan kuantitatif, yakni mendeskripsikan mengenai hubungan antara komitmen organisasi dan kecerdasan spiritual dengan $O C B$. Populasi dalam penelitian ini adalah Guru Tidak Tetap Yayasan (GTTY) pada 14 SMP Swasta yang berada di Kecamatan Jonggol Kabupaten Bogor dengan jumlah 136. Teknik pengambilan sampel menggunakan proportional random sampling dengan error margin 5\% dan jumlah sampel sebanyak 102 orang. Data penelitian dianalisis menggunakan statistik deskriptif dan statistic inferensial.

\section{HASIL DAN PEMBAHASAN}

\section{Pengujian Hipotesis}

1. Hubungan antara Komitmen Organisasi $\left(\mathrm{X}_{1}\right)$ dengan $O C B(\mathrm{Y})$.

Hipotesis pertama yang diajukan adalah "Terdapat hubungan antara Komitmen Organisasi dengan OCB (Y)". Berdasarkan hasil analisis regresi linier sederhana $X_{1}$ dan $Y$, diperoleh nilai $b=0,896$ dan nilai konstanta $a=28,342$. Sehingga persamaan regresi yang terbentuk antara variabel komitmen organisasi denganOCB yaitu $\hat{Y}=28,342+0,896 X_{1}$. Juga diperoleh nilai probabilitas $(\mathrm{sig}$,$) 0,000 < nilai 0,05$ dan 0,01 , dengan demikian persamaan regresi $\hat{\mathrm{Y}}=28,342+0,8967 \mathrm{X}_{1}$ sangat signifikan. Hasil pengujian ini mengkonfirmasi bahwa persamaan $\hat{Y}=28,342+0.896 \mathrm{X}_{1}$ adalah linier karena $F_{\text {hitung }}<\mathrm{F}_{\text {tabel }}=$ $0,2915<0,7197$, maka model regresi dapat dipergunakan meramalkan meramalkan $O C B$ berdasarkan skor komitmen organisasi.

Dari data diatas dapat disimpulkan bahwa semakin baik komitmen organisasi semakin tinggi pula $O C B$. Temuan dalam penelitian ini sekaligus menolak Ho yang menyatakan "tidak terdapat hubungan positing komitmen organisasi dengan pula $O C B$ dan menerima $\mathrm{H}_{1}$ yang menyatakan terdapat hubngan positif komitmen organisasi dengan $O C B$ ” Kekuatan hubungan Komitmen Organisasi (variabel $\mathrm{X}_{1}$ ) dengan $O C B$ (variabel $\mathrm{Y}$ ) dapat diketahui dari hasil perhitungan koefisien determinasinya. Besaran koefisien determinasi tersebut adalah sebesar $\left(\mathrm{r}_{\mathrm{y} 1}\right)^{2}=0,719$. Besaran ini memberikan pengertian bahwa $61,8 \%$ variasi $O C B$ dapat dijelaskan oleh variasi Komitmen Organisasi.

\section{Hubungan antara Kecerdasan Spiritual $\left(\mathrm{X}_{2}\right)$ dengan $O C B(\mathrm{Y})$.}

Hipotesis kedua yang diajukan adalah "Terdapat hubungan Kecerdasan Spiritual dengan $O C B$ (Y)". Berdasarkan hasil analisis regresi linier sederhana $\mathrm{X}_{1}$ dan $\mathrm{Y}$, diperoleh nilai $\mathrm{b}=0,895$ dan nilai konstanta $\mathrm{a}=28,342$. Sehingga persamaan regresi yang terbentuk antara variabel Kecerdasan spiritual denganOCB yaitu $\hat{\mathrm{Y}}=34,486+0,895 \mathrm{X}_{1}$. Juga diperoleh nilai probabilitas (sig,) $0,000<$ nilai 0,05 dan 0,01, dengan demikian persamaan regresi $\hat{Y}=34,486+0,895 \mathrm{X}_{1}$ sangat signifikan. Hasil pengujian ini mengkonfirmasi bahwa persamaan $\hat{Y}=34,846+0.895 X_{1}$ adalah linier, karena $F_{\text {hitung }}<F_{\text {tabel }}=0,0981<0,7197$, maka model regresi dapat dipergunakan meramalkan meramalkan $O C B$ berdasarkan skor komitmen organisasi.

Hasil analisis hubungan sederhana tersebut adalah bahwa terdapat hubungan yang positif antara Kecerdasan spiritual dengan $O C B$. Dengan demikian dapat disimpulkan bahwa semakin tinggi kecerdasan spiritual semakin tinggi pula $O C B$. Temuan dalam penelitian ini sekaligus menolak Ho yang menyatakan "tidak terdapat hubungan positing kecerdasan spiritual dengan pula $O C B$ dan menerima $\mathrm{H}_{1}$ yang menyatakan terdapat hubngan positif kecerdasan spiritual dengan $O C B$ ”. Kekuatan 
hubungan Kecerdasan spiritual (variabel $\mathrm{X}_{2}$ ) dengan $O C B$ (variabel $\mathrm{Y}$ ) dapat diketahui dari hasil perhitungan koefisien determinasinya. Besaran koefisien determinasi tersebut adalah sebesar $\left(\mathrm{r}_{\mathrm{y} 2}\right)^{2}=0,618$. Besaran ini memberikan pengertian bahwa $61,8 \%$ variasi $O C B$ dapat dijelaskan oleh variasi Kecerdasan Spiritual.

\section{Hubungan antara Komitmen Organisasi $\left(X_{1}\right)$ dan Kecerdasan Spiritual $\left(X_{2}\right)$ secara bersama-sama dengan $O C B(Y)$}

Berdasarkan hasil analisis persamaan regresi ganda antara pasangan data Komitmen Organisasi $\left(\mathrm{X}_{1}\right)$ dan Kecerdasan Spiritual $\left(\mathrm{X}_{2}\right)$ secara bersama-sama dengan $O C B(\mathrm{Y})$, diketahui bahwa nilai koefisien regresi ganda $\mathrm{b} 1=0,876, \mathrm{~b} 2=0,022$ dengan nilai konstanta a sebesar 28,104. Dengan demikian bentuk hubungan variabel Komitmen Organisasi $\left(\mathrm{X}_{1}\right)$ dan Kecerdasan Spiritual $\left(\mathrm{X}_{2}\right)$ secara bersama-sama dengan $O C B(\mathrm{Y})$ digambarkan dengan persamaan regresi, yaitu: $\hat{\mathrm{Y}}=28,104+$ $0,876 \mathrm{X}_{1}+0,022 \mathrm{X}_{2}$

Analisis korelasi ganda pasangan data Komitmen Organisasi $\left(\mathrm{X}_{1}\right)$ dan Kecerdasan Spiritual $\left(\mathrm{X}_{2}\right)$ dengan $O C B(\mathrm{Y})$ menghasilkan koefisien korelasi ganda $\mathrm{r}_{\mathrm{y} 12}$ sebesar 0,867. Rangkuman hasil analisis korelasi ganda antara Komitmen Organisasi $\left(\mathrm{X}_{1}\right)$ dan Kecerdasan Spiritual $\left(\mathrm{X}_{2}\right)$ dengan $O C B(\mathrm{Y})$ dan uji F. hasil analisis menunjukan bahwa besaran koefisien korelasi $\mathrm{r}_{\mathrm{y} 12}$ sebesar 0,867 berarti Komitmen Organisasi dan Kecerdasan Spiritual secara bersama-sama mempunyai hubungan positif dengan $O C B$. Dengan demikian berarti semakin baik komitmen organisasi dan kecerdasan spiritual, maka semakin baik pula $O C B$

\section{Korelasi Parsial}

Hasil perhitungan diperoleh besaran $\mathrm{r}_{\mathrm{y} 12}$ sebesar 0,5447. Uji signifikansi korelasi parsial menggunakan statistik uji " $\mathrm{t}$ " dan memperoleh hasil $t_{\text {hitung }}$ sebesar 5, 123. Besaran ini dikonsultasikan dengan $t_{\text {tabel }}$ dalam tingkat sangat signifikan 0,05; diperoleh $\mathrm{t}$ sebesar 1,960 atau $\mathrm{t}_{\text {hitung }}>\mathrm{t}_{\mathrm{tabel}}$. Dengan demikian koefisien korelsi parsial $\mathrm{r}_{\mathrm{y} 12}$ daopat dinyatakan sangat signifikan. Artinya adalah bahwa Komitmen Organisasi memberikan kontribusi yang signifikan (berarti) terhadap peningkatan $O C B$, berarti hubungan Komitmen Organisasi dengan $O C B$ tidak dipengaruhi oleh Kecerdasan Spiritual.

Analisis korelasi parsial dilakuakan antara variable $\mathrm{Y}$ dengan variable $\mathrm{X}_{2}$ dalam kondisi variable $\mathrm{X}_{1}$ dikontrol (tetap). Hasil perhitungan memperoleh besaran $r_{\mathrm{y} 21}$ sebesar 0,493 . Uji signifikansi koefisien korelasi parsial $r_{\mathrm{y} 21}$ menggunakan statistic uji " $t$ " dan memperoleh hasil $t_{\text {hitung }}$ sebesar 4,359. Besaran ini dikonsultasikan $t_{\text {tabel }}$ dalam tingkat signifikansi 0,05, diperoleh besaran $\mathrm{t}$ sebesar 1,960 atau $\mathrm{t}_{\text {hitung }}>\mathrm{t}_{\text {tabel }}$. Dengan demikian koefisien korelasi parsial $\mathrm{r}_{\mathrm{y} 21}$ dapat dinyatakan sangat signifikan. Artinya Kecerdasan Spiritual memberikan kontribusi yang berarti terhadap peningkatan $O C B$, berarti hubungan Kecerdasan Spiritual dengan $O C B$ tidak dipengaruhi oleh Komitmen Organisasi.

\section{Pembahasan Hubungan positif antara Komitmen Organisasi $\left(\mathrm{X}_{1}\right)$ dengan $O C B(\mathrm{Y})$}

Pengujian hipotesis pertama menyimpulkan bahwa hubungan positif yang sangat signifikan antara Komitmen Organisasi $\left(\mathrm{X}_{1}\right)$ dengan $O C B(\mathrm{Y})$ yang ditunjukan oleh nilai $\mathrm{t}_{\text {hitung }}$ sebesar 5,447 lebih besar daripada nilai $\mathrm{t}_{\text {tabel }}$ pada taraf signifikansi alpha 0,05 yaitu 1,960 atau 5,447>1,960. Pola hubungan kedua variable ini dinyatakan oleh persamaan $Y=a+b x 1$ atau $\hat{Y}=28,342+$ $0.896 \mathrm{X}_{1}$. Persamaan ini memberikan informasi bahwa setiap perubahan satu satuan tingkat komitmen organisasi mengakibatkan terjadinya perubahan $O C B(\mathrm{Y})$ sebesar 0,896 pada konstanta 28,342. Hasil analisis korelasi sederhana antara Komitmen Organisasi dengan $O C B$ diperoleh nilai koefisien korelasi $\mathrm{r}_{\mathrm{y} 1}$ sebesar 0,846 . Nilai ini memberikan pengertian bahwa keterkaitan antara Komitmen Organisasi dengan $O C B$ adalah positif, artinya semakin baik Komitmen Organisasi semakin baik pula $O C B$ tersebut. Demikian pula sebaliknya, semakin rendah Komitmen Organisasi semakin rendah pula $O C B$.

Besarnya sumbangan atau kontribusi variable Komitmen Organisasi terhadap $O C B$ dapat diketahui dengan jalan mengkuadratkan perolehan nilai koefisien korelasi sederhananya. Hasil pengkuadratan nilai koefisien korelasi sederhananya adalah sebesar 0,719. Secara statistik nilai ini memberikan pengertian bahwa kurang lebih 71,9\% variasi perubahan $O C B$ ditentukan/dijelaskan oleh Komitmen Organisasi dengan pola hubungan fungsionalnya oleh persamaan regresi tersebut di atas. Artinya jika seluruh guru Tidak Tetap Yayasan SMP Swasta se-Kecamatan Jonggol Kabupaten Bogor diuji, maka variasi pasangan skor kedua variable tersebut akan berdistribusi dan mengikuti pola hubungan variable Komitmen Organisasi dengan $O C B$ sesuai persamaan garis regresi $\mathrm{Y}=\mathrm{a}+\mathrm{bX}$ atau $\hat{Y}=28,342+0,896 \mathrm{X}_{1}$

Dari uraian dia atas diketahui bahwa Komitmen Organisai merupakan salah satu faktor yang mempengaruhi terbentuknya $O C B$ dimana diketahui bahwa komitmen organisasi merupakan suatu keinginan yang kuat untuk mengidentifikasi dan melibatkan diri dalam suatu organisasi untuk menjadi satu kesatuan dalam organisasi tersebut yang dibuktikan dengan sikap loyalitas untuk tetap bertahan menjadi anggota organisasi dan berusaha sekuat tenaga dalam mencapai tujuan organisasi. Dimensi komitmen oraganisasi meliputi: a. Komitmen Afektif, dengan indikatornya yaitu: 1) Merasa nyaman menjadi bagian organisasi, dan 2) Loyalitas terhadap organisasi, b. Komitmen Kontinuans (Komitmen Berkelanjutan), dengan indikatornya yaitu: 1) Adanya keuntungan bila bertahan dalam organisasi, dan 2) Adanya kerugian bila meninggalkan organisasi, c. Komitmen Normatif, dengan indikatornya yaitu:1) Kesanggupan melakukan pekerjaan denga penuh tanggung jawab, dan 2) Kesiapan bekerja keras untuk tujuan organisasi. Spector dalam Sopiah (2011: 254) mendefinisikan bahwa komitmen terhadap organisasi adalah: a. penerimaan terhadap tujuan-tujuan organisasi, b. kesediaan untuk bekerja keras bagi organisasi dan c. keinginan untuk tetap bekerja dalam organisasi. 
$O C B$ adalah perilaku kerja yang dimiliki oleh seorang guru dalam suatu organisasi atau lembaga yang dilakukan secara sukarela dan tidak mengharapkan imbalan di luar tugas pokok yang telah ditetepkan dan disepakati yang memberikan kontribusi kepada organisasi atau lembaga tempat guru bekerja, dengan indikator-indikatornya, yaitu: a. Altruism : menolong rekan kerja yang relevan dengan organisasi, b. Conscientiousness: Melampaui persyaratan minimum, c. Sportmanship: toleransi pada keadaan yang tidak ideal (menghindari keluhan), d. Courtesy: mencegah permasalahan yang berhubungan dengan pekerjaan, dan e. Civic virtue: bertanggungjawab dan berpartisipasi dalam kegiatan organisasi.

Ketika komitmen organisasi seorang guru di sekolah atau lembaga pendidikan terbina dengan baik dan terpeliharanya situasi dan kondisi lingkungan kerja yang nyaman dan kondusif, maka kerjanya sangat baik. Bahkan jika seorang guru merasa puas dan nyaman dengan situasi dan lingkungan kerjanya serta merasa nyaman menjadi bagian dari sekolah, menghasilkan kinerja yang extrarole atau sukrela guru yang biasa disebut $O C B$. Penelitian yang dapat mendukung penelitian ini adalah penelitian yang dilakukan oleh Ibrahim dan Aslinda (2015:58) tentang hubungan komitmen organisasi dengan OCB yang membuktikan bahwa Komitmen Organisasi berpengaruh positif dan signifikan terhadaap Organizational Citizenship Behavior, yang ditunjukan dengan nilai koefisien korelasi $(r)=0,380$ pada $\rho=0,05$ dan nilai signifikan $(\rho)=0,000(\rho=0,000<0,05)$, dari yang menyatakan semakin baik komitmen organisasi maka OCB akan meningkat

\section{Pembahasan Hubungan positif antara Kecerdasan Spiritual $\left(\mathrm{X}_{2}\right)$ dengan $O C B(\mathrm{Y})$}

Pengujian hipotesis pertama menyimpulkan bahwa hubungan positif yang sangat signifikan antara Kecerdasan Spiritual $\left(\mathrm{X}_{1}\right)$ dengan $O C B(\mathrm{Y})$ yang ditunjukan oleh nilai $\mathrm{t}_{\text {hitung }}$ sebesar 4,359 lebih besar daripada nilai $\mathrm{t}_{\text {tabel }}$ pada taraf signifikansi alpha 0,05 yaitu 1,960 atau 4,359>1,960. Pola hubungan kedua variable ini dinyatakan oleh persamaan $\mathrm{Y}=\mathrm{a}+\mathrm{bx}_{1}$ atau $\hat{\mathrm{Y}}=34,846+$ $0.895 \mathrm{X}_{1}$. Persamaan ini memberikan informasi bahwa setiap perubahan satu satuan tingkat Kecerdasan Spiritual mengakibatkan terjadinya perubahan $O C B(\mathrm{Y})$ sebesar 0,895 pada konstanta 34,846.

Hasil analisis korelasi sederhana antara Kecerdasan Spiritual dengan $O C B$ diperoleh nilai koefisien korelasi $\mathrm{r}_{\mathrm{y} 2}$ sebesar 0,786. Nilai ini memberikan pengertian bahwa keterkaitan antara Kecerdasan Spiritual dengan $O C B$ adalah positif, artinya semakin baik Kecerdasan Spiritual semakin baik pula $O C B$ tersebut. Demikian pula sebaliknya, semakin rendah Komitmen Organisasi semakin rendah pula $O C B$.

Besarnya sumbangan atau kontribusi variable Kecerdasan Spiritual terhadap $O C B$ dapat diketahui dengan jalan mengkuadratkan perolehan nilai koefisien korelasi sederhananya. Hasil pengkuadratan nilai koefisien korelasi sederhananya adalah sebesar 0,618. Secara statistik nilai ini memberikan pengertian bahwa kurang lebih $61,8 \%$ variasi perubahan $O C B$ ditentukan/dijelaskan oleh Kecerdasan Spiritual dengan pola hubungan fungsionalnya oleh persamaan regresi tersebut di atas. Artinya jika seluruh guru Tidak Tetap Yayasan SMP Swasta se-Kecamatan Jonggol Kabupaten Bogor diuji, maka variasi pasangan skor kedua variable tersebut berdistribusi dan mengikuti pola hubungan variable Kecerdasan Spiritual dengan $O C B$ sesuai persamaan garis regresi $\mathrm{Y}=\mathrm{a}+\mathrm{bX}$ atau $\hat{\mathrm{Y}}=34,846+0.895 \mathrm{X}_{1}$

Dari uraian dia atas diketahui bahwa Kecerdasan Spiritual merupakan salah satu faktor yang mempengaruhi terbentuknya $O C B$ dimana diketahui bahwa Kecerdasan Spiritual merupakan respon individu dalam bersikap fleksibel, kesadaran diri akan tujuan hidup, mampu menghadapi dan memanfaatkan penderitaan, menghadapi dan melampaui perasaan sakit, keengganan untuk menyebabkan kerugian, kualitas hidup, mampu berpandangan holistik dan kecenderungan bertanya Adapun indikator dari kecerdasan spiritual adalah: a) Sikap fleksibel, b) Tingkat kesadaran yang tinggi, c) Memiliki imajinasi, d) Memiliki kualitas hidup yang diilhami oleh nilai-nilai, dan e) Keterbukaan dan rasa ingin tahu. Kekuatan hubungan antara kecerdasan spiritual dengan OCB guru pada penelitian ini tercermin pada nilai koefisien korelasi sebesar $\left(\mathrm{r}_{\mathrm{y} 2}\right)=0,786$ dan hasil uji $\mathrm{F}=4,539$

Penelitian yang dapat mendukung penelitian ini adalah penelitian Moosapour, Feizi, Alipour (2013 : 74-75) tentang hubungan kecerdasan spiritual dengan OCB yang membuktikan bahwa kecerdasan spiritual memiliki hubungan positif dan signifikansi yang kuat terhadap OCB. Hasil ini ditunjukan dengan nilai koefisien korelasi $(r)=0,609(\rho<0,000)$. Berdasarkan uraian di atas, maka kecerdasan spiritual merupakan salah satu faktor dalam meningkatkan OCB

\section{Pembahasan Hubungan positif antara Komitmen Organisasi $\left(X_{1}\right)$ dan Kecerdasan Spiritual $\left(X_{2}\right)$ secara bersama-sama dengan $O C B(Y)$}

Pengujian hipotesis menyimpulkan bahwa terdapat hubungan positif yang sangat signifikan antara Komitmen Organisasi dan Kecerdasan Spiritual secara bersama-sama dengan $O C B$. Pola Hubungan ketiga variabel yang dinyatakan oleh persamaan regresi ganda $\hat{Y}=28,104+0,876 X_{1}+0,022 X_{2 . .}$ Persamaan ini memberikan informasi bahwa setiap perubahan satu unit skor Komitmen Organisasi dan Kecerdasan Spiritual satu satuan mengakibatkan terjadinya perubahan Organization Citizenship Behavior sebesar 0,876 dan 0,022 pada konstanta 28,104. Hasil analisis korelasi ganda antara Komitmen Organisasi dan Kecerdasan Spiritual diperoleh nilai koefisien korelasi ganda sebesar ry12 sebesar 0,867. Nilai ini menunjukkan bahwa keterkaitan antara Komitmen Organisasi dan Kecerdasan Spiritual secara bersama-sama dengan $O C B$ adalah positif.

Besarnya sumbangan atau kontribusi variabel Komitmen Organisasi dan Kecerdasan Spiritual secara bersama-sama dapat diketahui melalui nilai koefisien determinasi sebesar 0,867. Hasil analisis tersebut menunjukkan bahwa lebih kurang $71,9 \%$ variasi perubahan $O C B$ ditentukan/dijelaskan oleh Komitmen Organisasi dan Kecerdasan Spiritual secara bersama-sama dengan pola hubungan fungsionalnya seperti ditunjukkan oleh persamaan regresi tersebut di atas. Artinya jika seluruh guru 
diteliti Komitmen Organisasi dan Kecerdasan Spiritual secara bersama-sama dengan melihat $O C B$, maka variasi pasangan skor ketiga variabel mengikuti pola persamaan regresi $\hat{Y}=28,104+0,876 \mathrm{X}_{1}+0,022 \mathrm{X}_{2}$. Dengan demikian berarti semakin tinggi Komitmen Organisasi dan semakin tinggi Kecerdasan Spiritual, semakin tinggi pula OCB. Sebaliknya semakin rendah Komitmen Organisasi dan Kecerdasan Spiritual, semakin rendah pula $O C B$. Untuk mengetahui kontribusi murni masing-masing variabel bebas dengan variable terikat telah dilakukan analisis korelasi parsial. Kontribusi murni masing-masing variable diketahui dengan melakukan pengontrolan variabel bebas lain. Hasil analisis tersebut dilaporkan berikut ini:

Pertama, Kontribusi murni variabel bebas Komitmen Organisasi dengan $O C B$ jika Kecerdasan Spiritual dalam keadaan konstan, diperoleh nilai sebesar 71,9\%. Kondisi ini menunjukkan bahwa adanya kontribusi Komitmen Organisasi terhadap $O C B$. Dengan demikian Komitmen Organisasi bukanlah satu-satunya variabel yang dapat menentukan $O C B$, melainkan masih ada variabel lain yaitu Kecerdasan Spiritual yang ikut berpengaruh.

Kedua, Kontribusi murni variabel bebas Kecerdasan Spiritual dengan $O C B$ jika Komitmen organisasi dalam keadaan konstan, diperoleh nilai sebesar $61,8 \%$. Kondisi ini menunjukkan bahwa adanya kontribusi Kecerdasan Spiritual terhadap $O C B$, yang berarti bahwa Kecerdasan Spiritual bukanlah satu-satunya variabel yang dapat menentukan $O C B$, melainkan masih ada variabel lain yaitu Komitmen Organisasi yang ikut mempengaruhi.

Berdasarkan uraian tersebut di atas, maka dapat diketahui bahwa variabel bebas yang mempunyai hubungan yang paling kuat dan kontribusi yang paling besar dengan variabel terikat adalah Komitmen Organisasi. Ketiga, Kontribusi murni variabel bebas Komitmen Organisasi dan Kecerdasan Spiritual secara bersama-sama dengan OCB jika Komitmen Organisasi dan Kecerdasan Spiritual dalam keadaan konstan, diperoleh nilai sebesar 75,2\% persen. Kondisi ini menunjukkan bahwa kontribusi Komitmen Organisasi dan Kecerdasan Spiritual terhadap $O C B$, yang berarti bahwa Komitmen Organisasi dan Kecerdasan Spiritual bukanlah satu-satunya variabel yang dapat menentukan $O C B$, melainkan masih ada variabel lain yang mempengaruhi.

\section{SIMPULAN}

Berdasarkan temuan penelitian diatas dapat disimpulkan bahwa terdapat hubungan positif sangat signifikan antara komitmen krganisasi dengan Organization Citizenship Behavior (OCB), terdapat hubungan antara kecerdasan spiritual dengan Organization Citizenship Behavior $(O C B)$ dan terdapat hubungan antara komitmen organisasi dan kecerdasan spiritual secara bersama-sama dengan organization citizenship behavior (OCB). Berdasarkan hasil penelitian ini maka untuk meningkatkan organization citizenship behavior $(O C B)$ dapat dilakukan upaya dengan mengembangkan dan memperbaiki komitmen organisasi dan kecerdasan spiritual.

\section{REFERENSI}

Colquit, Jason A, Lapine and Michael J Waston, (2009). Organization Behavior Improving Performance and Commitment, Boston: Mcgraw Hill.

Esmaili, M., Zareh, H., \& Golverdi, M. (2014). Spiritual intelligence: Aspects, components and guidelines to promote it. International Journal of Management, Accounting and Economics, 1(2), 2383-2126.

Hidayat, Rais. (2017). Tinjauan Teoretik Tentang Komitmen Organisasi Guru. Pedagonal| Jurnal Ilmiah Pendidikan, Vol.1 No.2, PP. 62 - 70

Luthans, Fread, (2011). Organizational Beavior, (New York : McGraw-Hill Irwin).

Patras, Yuyun. (2017). Pengaruh Perilaku Kepemimpinan, Keadilan Organisasi Dan Keterlibatan Kerja Terhadap Organizational Citizenzhip Behavior Dosen. Pedagonal| Jurnal Ilmiah Pendidikan, Vol.1 No.1, PP. 8-14

Organ, D. W. (2006). Organizational Citizenship Behavior: The Good SoldierSyndrome. Lexington, MA:Lexington Books.

Podsakoff, P.M. and MacKenzie, S.B., (1994). Organizational Citizenship Behaviors and Sales Unit Effectiveness, Journal of MarketingResearch, 3(1), 351-363

Gibson. (2008). Manajemen Sumber Daya Manusia, Edisi Keempat,Erlangga, Jakarta.

Kreitner, Robert dan Kinicki, Angelo. (2014). Perilaku Organisasi, Organizational Behavior, Edisi 9. Jakarta: Salemba Empat.

Moosapour, Sodeif, Mohammad Feizi and Hosein Alipour. (2013). Spiritual Intelligence Relationship withOrganizational Citizenship Behavior of High SchoolTeachers in Germi City.Journal of BusinessManagement \& Social Sciences Research. Vol.2 No.10: 72-75.

Muhammad Akmal Ibrahim, Aslinda Aslinda. (2014). The Effect of Motivation on Organizational Citizenship Behavior (OCB) at Telkom Indonesia in Makassar. Jurnal Ilmu Administrasi dan Organisasi. Vol 21, No 2 Universitas Indonesia.

Sopiah. (2011). Perilaku Organisasional, CV. Andi Offset, Yogyakarta

Sutrisno, Edy. (2010). Budaya Organisasi. Kencana Prenada Media Group : Jakarta

Buzan, Tony, 2003 Power Spiritual Intelligence: Sepuluh Cara Jadi Orang yang Cerdas Secara Spiritual, Jakarta: PT. Gramedia Pustaka Utama

Zohar, D., \& Marshall, I. (2007). (SQ) Kecerdasan Spiritual. Bandung: Mizan. 